\section{ON THE PERFORMANCE OF STEEL WIRE ROPE AS THE EXTERNAL STRENGTHENING OF RC BEAMS WITH DIFFERENT END- ANCHOR TYPES}

Yanuar Haryantoa*, Buntara Sthenly Ganb, Arnie Widyaningruma, Nanang Gunawan Wariyatnoa, Ari Fadlic

aDepartment of Civil Engineering, Faculty of Engineering, Jenderal Soedirman University, Purwokerto, Indonesia bDepartment of Architecture, College of Engineering, Nihon University, Koriyama, Japan

cDepartment of Electrical Engineering, Faculty of Engineering, Jenderal Soedirman University, Punwokerto, Indonesia
Article history

Received

2 September 2017

Received in revised form

9 May 2018

Accepted

1 June 2018

Published online

1 August 2018

*Corresponding author yanuar_haryanto@unsoed.ac.id
Graphical abstract
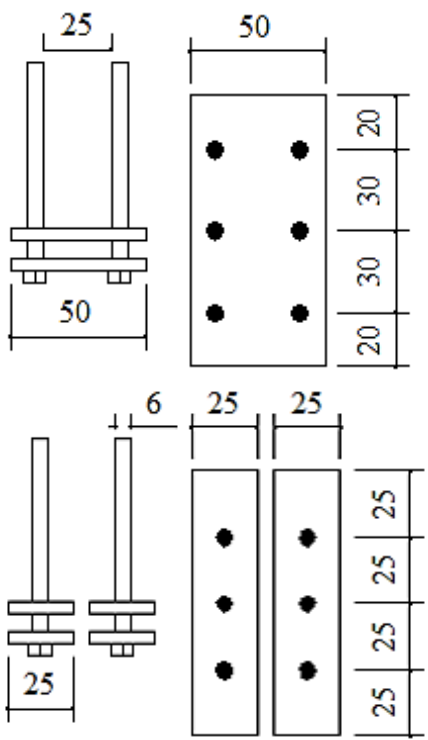

\begin{abstract}
This work investigated the performance of steel wire rope as an external strengthening for reinforced concrete beams with different end-anchor types. A study is conducted on reinforced concrete beams with the size of $100 \mathrm{~mm} \times 150 \mathrm{~mm} \times 1000 \mathrm{~mm}$, consisting of 1 beam without strengthening (BTP); 1 beam strengthened with 2 steel wire ropes of diameter $6 \mathrm{~mm}$ with end-anchor type 1 (BPA1); and 1 beam strengthened with 2 steel wire ropes of diameter $6 \mathrm{~mm}$ with end-anchor type 2 (BPA2). It is found that the external strengthening of reinforced concrete beams using steel wire rope has the advantage of better serviceability due to its higher ductility than the beam without strengthening. The load-carrying capacity of reinforced concrete beams, which are externally strengthened with steel wire ropes, shows a significant increase of up to $60 \%$. All specimens meet the minimum ductility requirements; in this case, the strengthening beams have other advantages, i.e. improved performance in preventing brittle failure. In this study, the increased stiffness is associated proportionately with the increased strength. This is supported by previous findings which suggest that the stiffness cannot be completely separated and independent of the strength. The failure in all specimens appeared in the same phases and all specimens experienced flexural failure. The ratios of end-anchor type 1 to end-anchor type 2 were close to 1 for all the parameters studied, which means that both types of end-anchor make an equally good contribution to the performance of steel wire rope.

Keywords: End-anchor, external strengthening, ductility, load-carrying capacity, steel wire rope
\end{abstract}

(C) 2018 Penerbit UTM Press. All rights reserved

\subsection{INTRODUCTION}

One of the critical parameters in a building is the resistance and strength of its structure in withstanding different loads such as wind load. Wind load works perpendicularly or horizontally to the height of buildings. For high-rise buildings, the wind load must be taken into account during planning and designing. The wind load acting on the structure of a building depends on wind speed, air density, geographical location, shape and height of the building, as well as stiffness of the structure. A building 
which is located in the trajectory of wind may cause the wind to turn or stop. As a result, the kinetic energy of the wind will transform into potential energy in the form of pressure or suction on the building. One important factor that affects the magnitude of pressure and suction on a building at the time the wind moves is wind speed. The magnitude of wind speed varies for each geographical location. The plan wind speed is usually based on data recorded for a 50-year period. The wind speed increases with an increase in height above the ground, and so does the value of plan wind speed. If the wind speed is known, the wind pressure acting on a building can be determined and expressed in an equivalent static force.

Pusposutardjo [1] argues that the wind is basically a vector that can be expressed by the direction and speed of the shift because wind is a movement of air masses in a horizontal direction. A hurricane is a strong wind with a speed of $123-135 \mathrm{~km} / \mathrm{h}$ that appears very fast. At a speed of $79-91 \mathrm{~km} / \mathrm{h}$, slight damage begins to occur to buildings and the damage can be more severe if the speed increases. In addition to wind speed and direction, time also determines the extent of damage. A building exposed to wind may experience damage due to collision, torsion and suction. Damage due to collision or suction occurs when the wind blows in a perpendicular direction to the building, while windinduced torsional damage occurs when the wind is in the form of cyclone or tornado [2]. Since there is a risk of building collapse due to environmental effects $[3,4]$ such as increase in wind load, structural strengthening is required. Considerations of efficiency and budgetary constraints make the alternative of strengthening preferable to replacement with a new structure [5]. Steel wire rope, which has the advantage of high flexibility [6], can be used as a strengthening material on structural elements. This work investigates the performance of steel wire rope as an external strengthening for reinforced concrete beams with various end-anchor types.

The potential use of steel wire rope as reinforcement for concrete, which has been studied previously [7], is based on utilising another advantage of steel wire rope, i.e. its high tensile strength. A series of previous studies on reinforced concrete beams strengthened with steel wire ropes have shown very promising results [8-10]. In Indonesia, the use of steel wire rope as a strengthening material was first studied by Haryanto [11]; this study showed that the flexural strength of reinforced concrete Tbeams in the region of negative moment increased via a bonded strengthening system and a ratio of 2.03 was obtained. Other studies showed that the flexural strength in the region of positive moment increased and had a ratio of 1.86 [12]. Optimisation via an initial pre-stressing force on the bonded strengthening and two pieces of steel wire rope shows that an initial pre-stressing force of $20 \%$ gave the highest flexural strength improvement [13, 14]. Another method involved the addition of steel rebars in a compression block for reinforced concrete Tbeams which were strengthened with steel wire ropes in the region of negative moment; this method resulted in an increase in flexural strength and had a ratio of 2.93 [15].

Studies on end-anchor types have been conducted previously by Sukrawa and Widiarsa [16] who concluded that there is an increase in flexural capacity of a beam with a GFRP strengthening sheet of $31.373 \%$ for end-anchor type fasteners; the said increase for an end-anchor comprising U-shape straps and bolts is $18.3 \%$ and $22.876 \%$ respectively. Jumaat and Alam [17] argue that failure at the end of the specimen may be prevented with the presence of an L- or U-shaped anchor on a beam strengthened with steel plate. L-shaped anchors perform better than U-shaped anchors. Furthermore, in the study, it is noted that the addition of an anchor in the middle of a previous anchorage system may be able to prevent the growth and spread of cracks [18]. According to Ahmed et al. [19], an end-anchor also affects the performance of reinforced concrete beams which are strengthened with CRFP plate. With the use of a wood anchor for pre-stressing on wastetire reinforced concrete as investigated by Maryoto [20], it was shown that pre-stressed concrete beams with a wooden anchor have a slightly higher flexural capacity when compared to pre-stressed concrete beams with a steel clamp anchor.

\subsection{METHODOLOGY}

\subsection{Material Properties}

The materials used for manufacturing concrete mix were multi-purpose cement type PPC (Pozzolan Portland Cement), fine aggregate of natural sand and coarse aggregate obtained from the local stone crusher. The fine aggregate possessed a specific gravity of 2.53 and had a fine modulus of 3.02. The coarse aggregate possessed a specific gravity of 2.65 and had a maximum aggregate size of $20 \mathrm{~mm}$. The composition of concrete mixture consisted of 203 $\mathrm{kg} / \mathrm{m}^{3}$ water, $822 \mathrm{~kg} / \mathrm{m}^{3}$ sand, $873 \mathrm{~kg} / \mathrm{m}^{3}$ gravel and $38 \mathrm{~kg} / \mathrm{m}^{3}$ cement with a w/c ratio of 0.46 . The average concrete compressive strength at 28 days was $26.95 \mathrm{MPa}$. The yield strength and tensile strength of $6 \mathrm{~mm}$ diameter steel, which were used as reinforcement, were $236.74 \mathrm{MPa}$ and $369.40 \mathrm{MPa}$ respectively. The steel wire rope, Independent Wire Rope Core (IWRC) with $6 \mathrm{~mm}$ diameter (Figure 1), was used as a strengthening material and had a tensile strength of $599.48 \mathrm{MPa}$. The results of a tensile test of the steel reinforcement and steel wire rope are shown in Figure 2. 

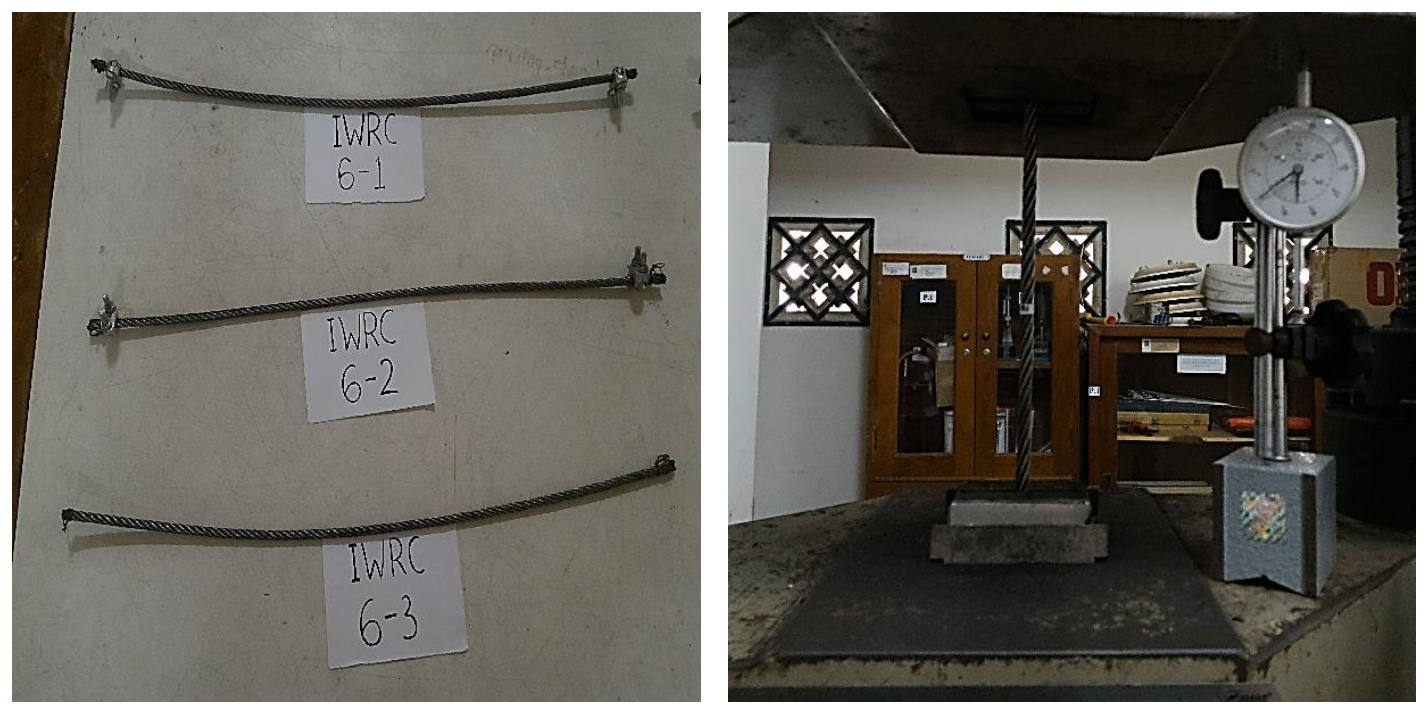

Figure 1 Independent Wire Rope Core (IWRC) with $6 \mathrm{~mm}$ diameter

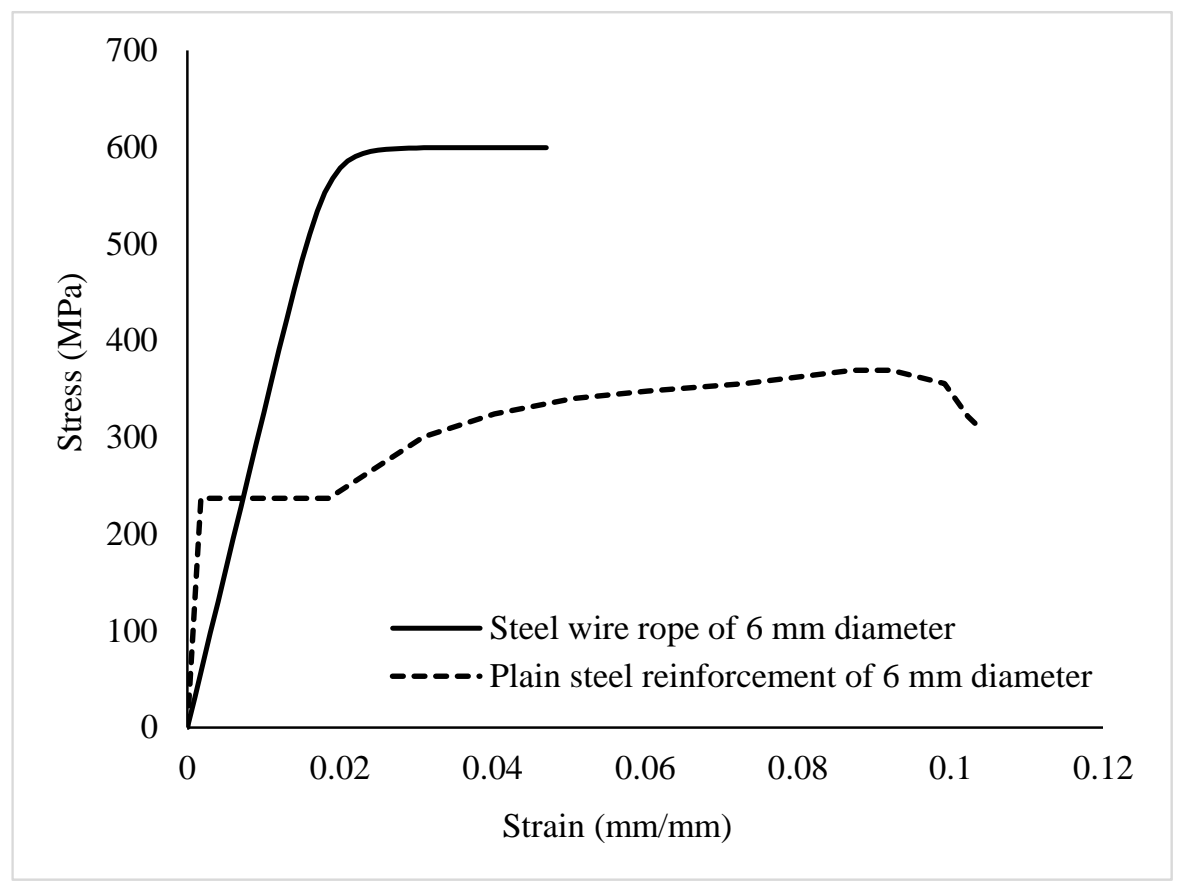

Figure 2 The result of tensile test of plain steel reinforcement and steel wire rope

\subsection{Beams Design}

The specimen of reinforced concrete beams as shown in Figure 3 which has the size of $100 \mathrm{~mm} \times 150$ $\mathrm{mm} \times 1000 \mathrm{~mm}$ consisted of 1 beam without strengthening (BTP), 1 beam strengthened by 2 steel wire ropes with diameter $6 \mathrm{~mm}$ and end-anchor type 1 (BPA1), and 1 beam strengthened by 2 steel wire ropes of diameter $6 \mathrm{~mm}$ and end-anchor type 2 (BPA2). The detailed specification of the reinforced concrete beam specimen is presented in Table 1. The ratio of tension reinforcement was $0.43 \%$ and $0.87 \%$ respectively for beam without strengthening and strengthening beams, while the ratio of shear reinforcement was $1.13 \%$ for both beams without strengthening and strengthening beams. The end-anchor used in this study was a Dynabolt which has $6 \mathrm{~mm}$ diameter, combined with a steel plate which has the thickness of $2 \mathrm{~mm}$ with the size of $50 \mathrm{~mm} \times 100 \mathrm{~mm}$ for endanchor type 1 (single plate) and the size of $25 \mathrm{~mm} x$ $100 \mathrm{~mm}$ for end-anchor type 2 (double plate). Dynabolt and steel plates which were used as the end-anchor is shown in Figure 4, while the detail of the end-anchor is illustrated in Figure 5. 
Table 1 Specification detail of reinforced concrete beam specimen

\begin{tabular}{|c|c|c|c|c|c|c|c|c|}
\hline \multirow[t]{2}{*}{ Code } & \multirow{2}{*}{$\stackrel{\mathrm{L}}{(\mathrm{mm})}$} & \multirow{2}{*}{$\begin{array}{c}\mathrm{b} \\
(\mathrm{mm})\end{array}$} & \multirow{2}{*}{$\begin{array}{c}\mathrm{h} \\
(\mathrm{mm})\end{array}$} & \multicolumn{2}{|c|}{$\begin{array}{c}\text { Longitudinal } \\
\text { Reinforcement }\end{array}$} & \multirow[t]{2}{*}{ Stirrups } & \multirow{2}{*}{$\begin{array}{l}\text { Steel Wire } \\
\text { Rope }\end{array}$} & \multirow[t]{2}{*}{ End-anchor } \\
\hline & & & & Tensile & Compressive & & & \\
\hline BTP & 1000 & 100 & 150 & $2 \varnothing 6$ & $2 \varnothing 6$ & $\varnothing 6-50$ & - & - \\
\hline BPA1 & 1000 & 100 & 150 & $2 \varnothing 6$ & $2 \varnothing 6$ & $\varnothing 6-50$ & $2 \varnothing 6$ & single plate \\
\hline BPA2 & 1000 & 100 & 150 & $2 \varnothing 6$ & $2 \varnothing 6$ & $\varnothing 6-50$ & $2 \varnothing 6$ & double plate \\
\hline
\end{tabular}

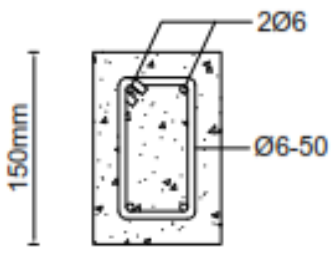

$100 \mathrm{~mm}$

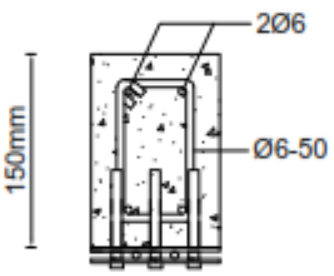

$100 \mathrm{~mm}$

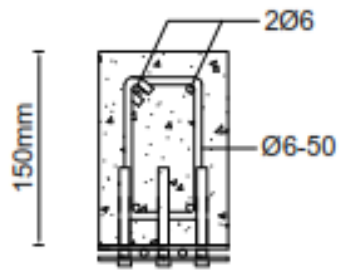

$100 \mathrm{~mm}$

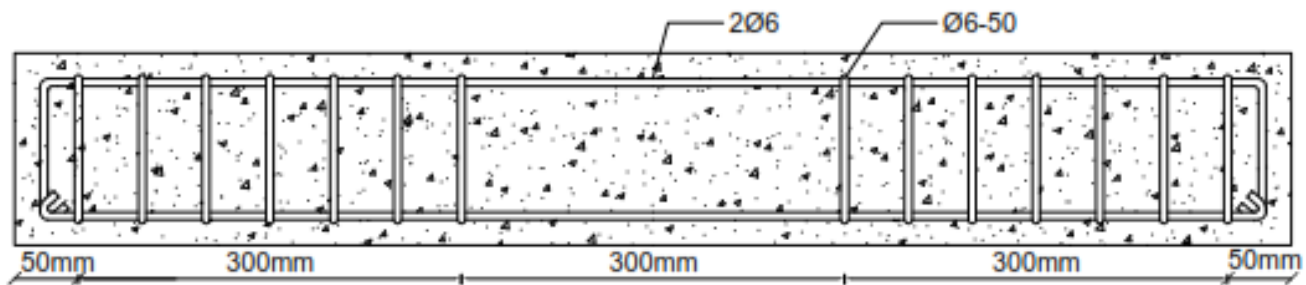

(a)

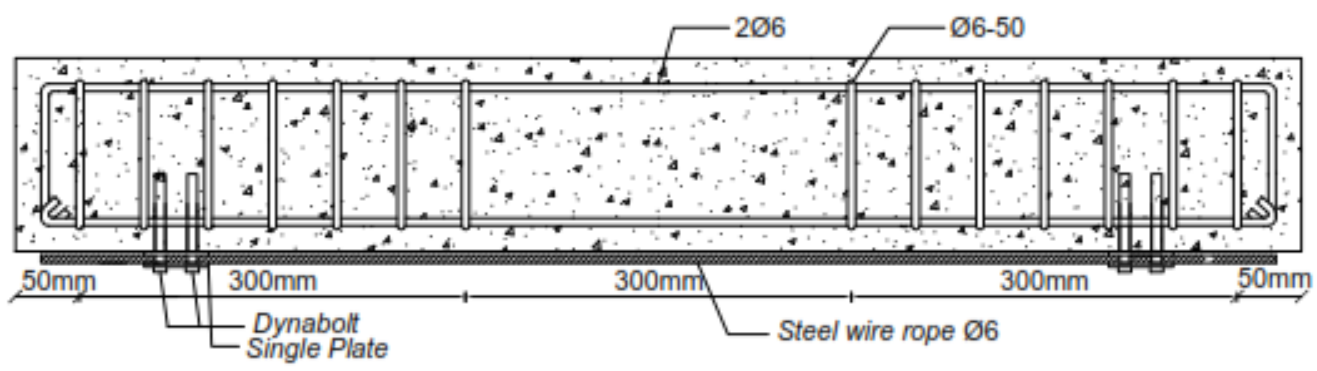

(b)

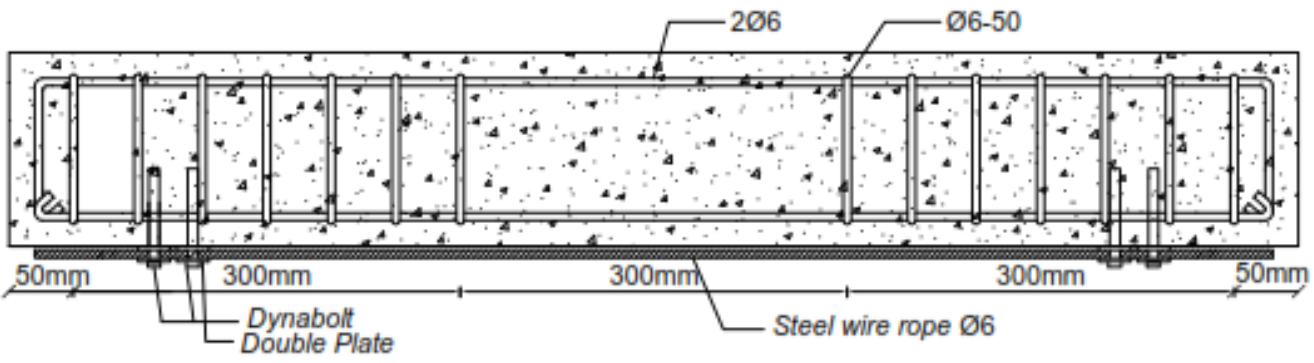

(c)

Figure 3 Specimen of reinforced concrete beam: (a) beam without strengthening (BTP); (b) strengthened beam with end-anchor type 1 (BTA1); (C) strengthened beam with end-anchor type 2 (BTA2)
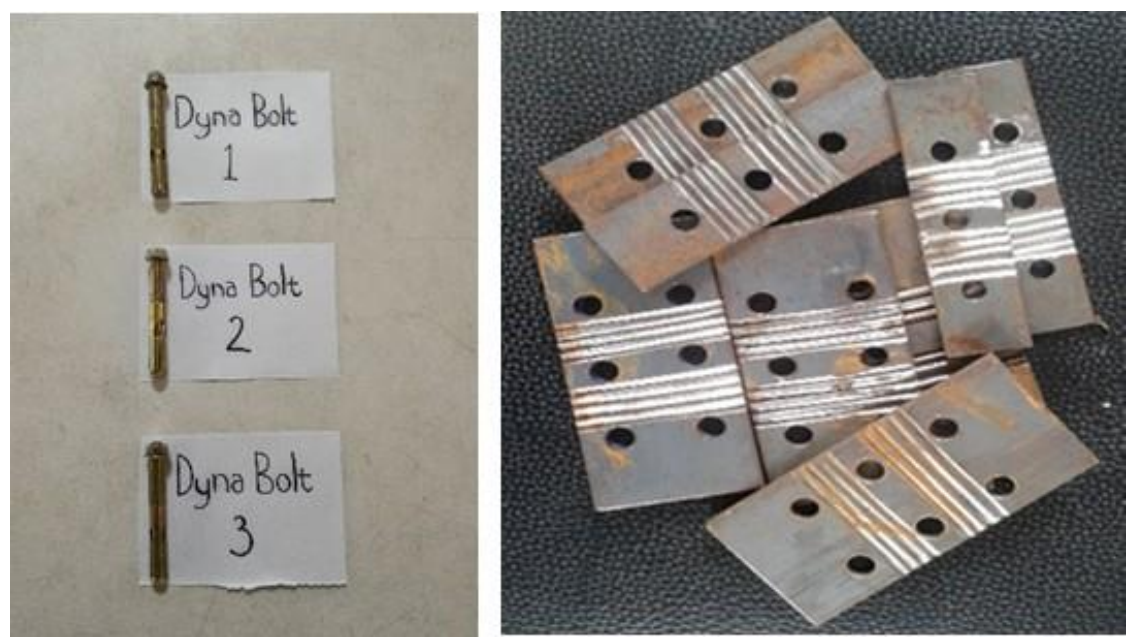

Figure 4 Dynabolt and steel plates used as end-anchor 

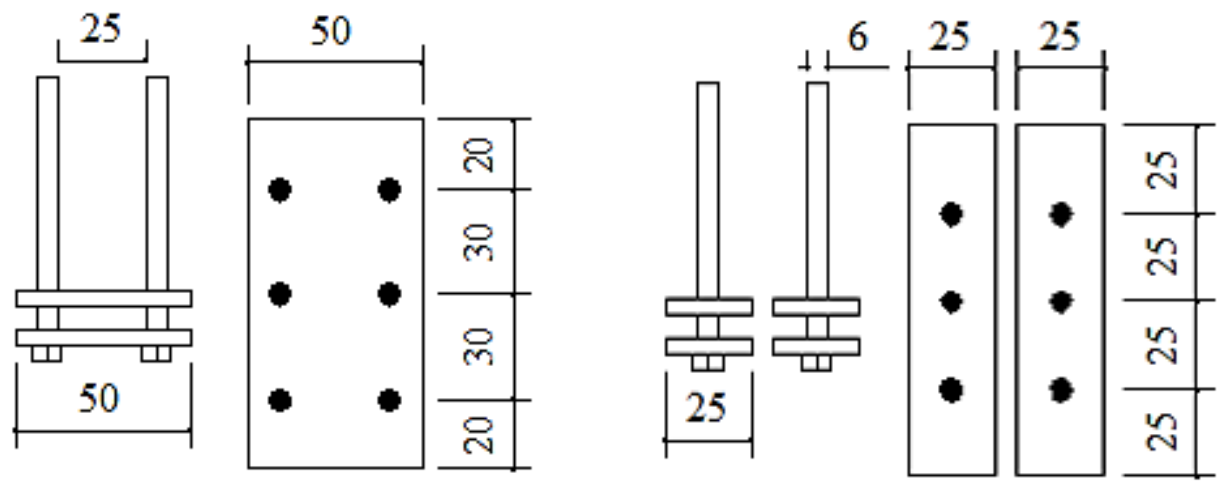

Figure 5 Detail of end-anchor: (a) type 1 (single plate); (b) type 2 (double plate)

\subsection{Strengthening Installation}

The strengthening installation process is illustrated in Figure 6. The initial phase of strengthening installation began by determining the location of the reinforcement in the reinforced concrete beam that was about to be strengthened by using a rebar scanner. Next, we marked these sites and determined the drilling points with the objective that the drill should not touch the existing reinforcement

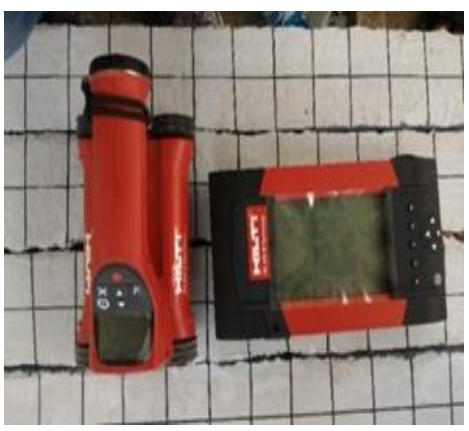

(a)

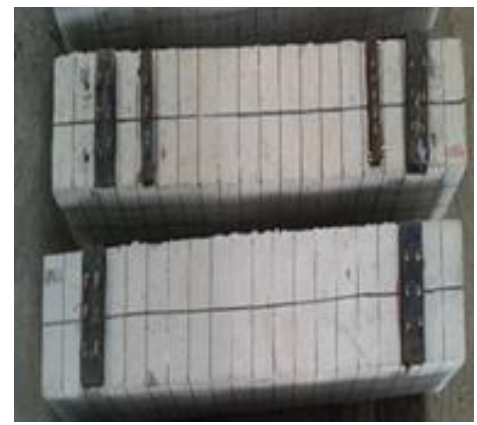

(c) during the drilling process of mounting the Dynabolt. Afterwards, we proceeded to drill the reinforced concrete beam until the surface reached a depth of $6 \mathrm{~cm}$. Dust from the drilling was cleaned using an air compressor, and the holes that had been cleaned were filled with a chemical bonding agent. Afterwards, we installed the Dynabolt and steel plate serving as the end-anchor and then installed the steel wire rope and clamp. The final stage was tightening the Dynabolt at the end-anchor.

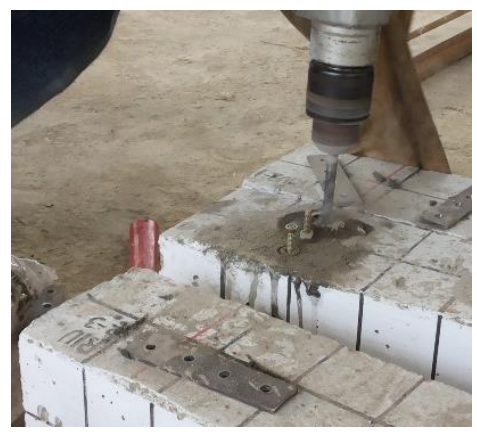

(b)

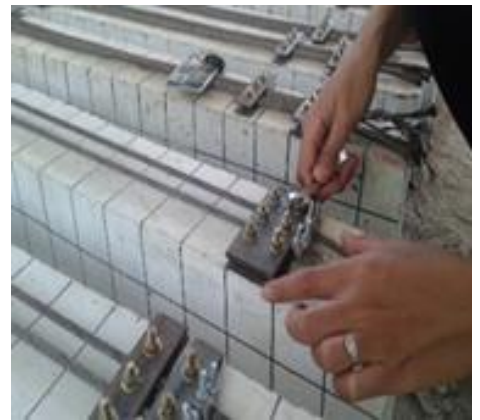

(d)

Figure 6 Strengthening installation process: (a) determining the position of existing reinforcement using rebar scanner; (b) drilling; (c) installing Dynabolt and steel plate used as the end-anchor;

(d) installing steel wire rope and tightening Dynabolt 


\subsection{RESULTS AND DISCUSSION}

The results of the research on the performance of steel wire rope as the external strengthening for reinforced concrete beams with different endanchor types will be explained through the loaddeflection curve parameter, load-carrying capacity, ductility and stiffness, as well as the failure mode of the specimens.

\subsection{Load-Deflection Curve}

Figure 7 shows the load-deflection curves for the test specimens BTP, BPA1 and BPA2. The curves, which exhibit the ultimate deflection equal to the deflection where the load has fallen to $80 \%$ of the peak load after attaining the peak, show that there was an increased linear deflection before the collapse in all specimens. The strengthened beams had higher deflection than the unstrengthened beam, which recorded $71.81 \%$ and $60.89 \%$ respectively for BPA1 and BPA2. The result signifies that the strengthened beam had the advantage of better serviceability. Figure 7 also shows that the two strengthened beams had a nearly equal deflection with the ratio of 1.07, which means that both endanchor types contributed equally well to the performance of steel wire rope in producing inelastic deformation.

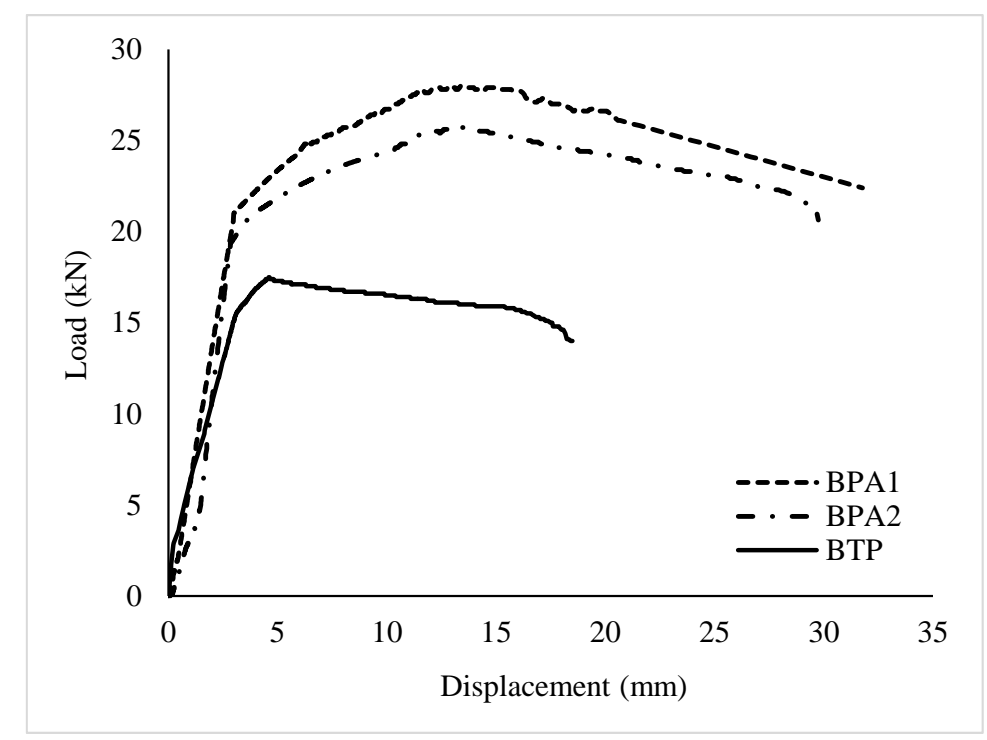

Figure 7 Load-deflection curves

\subsection{Load-Carrying Capacity}

The load-carrying capacities of all specimens in this study were compared with the result of theoretical sectional analysis and are presented in Figure 8. The results of the study showed that the load-carrying capacities of specimens BTP, BPA1 and BPA2 were $17.5 \mathrm{kN}, 28 \mathrm{kN}$ and $25.8 \mathrm{kN}$ respectively. In this study, the load-carrying capacities of BPA1 and BPA2 were found to have increased by $60.00 \%$ and $47.44 \%$ correspondingly with the use of steel wire rope as external strengthening. From Figure 8, we also know that the load-carrying capacity of both strengthened beams had a ratio of 1.09. Thus, for application in the field, the performance of steel wire rope in supporting the load will inevitably be affected equally well by both types of end-anchor. 


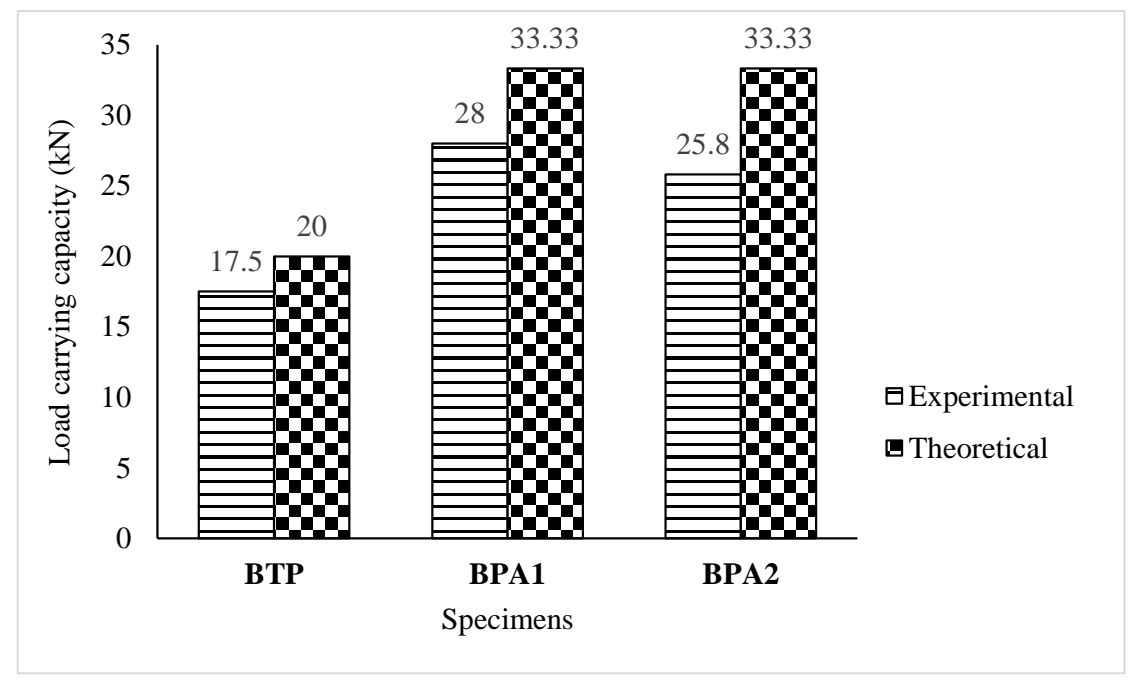

Figure $\mathbf{8}$ Load-carrying capacity

Figure 9 shows the analytical model to determine the theoretical load-carrying capacity. In Figure 9, the assumed basic analytical conditions of internal strain, stress and resultant force for a steel wire ropestrengthened section at ultimate stage is depicted. Both strain compatibility and internal force equilibrium in the analytical model were assumed to have associated the stress within the steel wire rope with the applied moment. It is clear that the addition of steel wire rope in the tensile zone will result in increased tensile force on the cross section of the beam. The tensile force component with its corresponding distance causes the moment capacity to increase, hence causing the loadcarrying capacity of the cross-section of the beam to increase as well. Finally, the assumption of perfect bond between different materials in theoretical sectional analysis will bring forth load-carrying capacity which is higher than the results obtained from the experimental test.

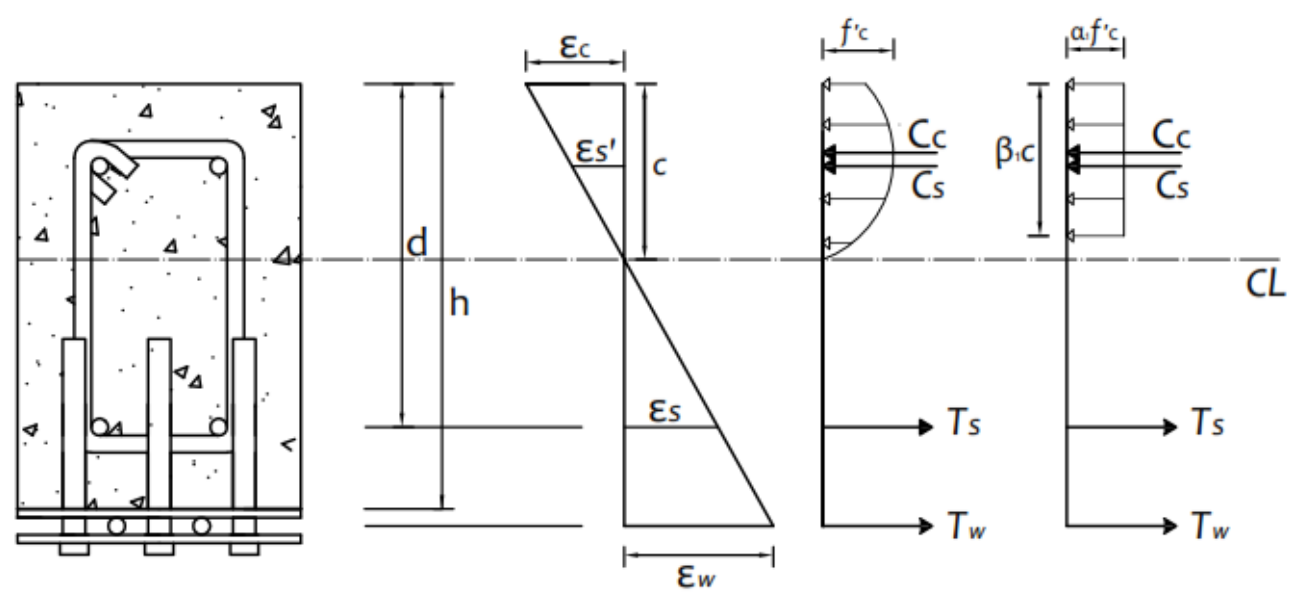

Figure 9 Analytical model at the ultimate stage

\subsection{Ductility and Stiffness}

Ductility is the ability of a structure or structural element to inelastically deform without substantially losing strength [21]. To determine the ductility of a structure or element structure, the ductility index, which is the ratio of ultimate deflection to yield deflection, is used [22]. Ultimate deflection is considered as the deflection where the load has fallen to $80 \%$ of the peak load after attaining the peak. Conversely, the yield deflection is referred to as the deflection at the hypothetical yield point of an equivalent elasto-plastic system whereby its equivalent elastic stiffness is considered as the secant stiffness at $75 \%$ of the peak load before attaining the peak load with the yield strength being considered as the peak load. The ductility indexes for BTP, BPA2 and BPAl specimens were $7.46,8.88$ and 8.70 respectively as presented in Table 2 . All specimens met the minimum ductility requirements index of 3.00 $[23,24]$ and also met the minimum index ductility of $3.32[25,26]$. From Table 2, it was found that the increase of ductility in the strengthened beam was $19.02 \%$ for BPAl and $16.67 \%$ for BPA2. Both 
strengthened beams had a ductility index ratio of 1.02, which indicates that both types of end-anchor contributed equally well to the performance of the steel wire rope in terms of preventing a brittle failure.

Table 2 Ductility

\begin{tabular}{ccccc}
\hline \multirow{2}{*}{ Code } & $\boldsymbol{\delta}_{\mathbf{y}}$ & $\boldsymbol{\delta}_{u}$ & \multicolumn{2}{c}{ Ductility Index } \\
\cline { 4 - 5 } & $(\mathbf{m m})$ & $(\mathbf{m m})$ & $\boldsymbol{\mu}$ & $\boldsymbol{\%}$ \\
\hline BTP & 2.48 & 18.50 & 7.46 & - \\
BPA1 & 3.58 & 31.78 & 8.88 & 19.02 \\
BPA2 & 3.42 & 29.76 & 8.70 & 16.76 \\
\hline
\end{tabular}

Stiffness is an important parameter of the performance of a structure or structural element. The stiffness for all specimens in this study is presented in Table 3. The stiffness of the test specimens BTP, BPA1 and BPA2 was $7056.45 \mathrm{~N} / \mathrm{mm}, 7821.23 \mathrm{~N} / \mathrm{mm}$ and $7543.86 \mathrm{~N} / \mathrm{mm}$ respectively. The increases of stiffness in the beam reinforcement were $10.84 \%$ and $6.91 \%$ respectively for BPA1 and BPA2. In this study, the increase in stiffness generated was associated proportionately with the increase in load-carrying capacity. This supports the previous findings, which suggest that the stiffness cannot be completely separated and independent of the strength [27, 28]. The steel wire rope as a strengthening material generated an increased stiffness because the stiffness was also affected by the material performance [29]. In this case, the two types of endanchor had an equally good effect on the stiffness of the strengthening with the ratio of 1.03 .

Table 3 Stiffness

\begin{tabular}{ccccc}
\hline \multirow{2}{*}{ Code } & $\mathbf{P}_{\mathbf{y}}=\mathbf{P}_{\mathbf{u}}$ & $\boldsymbol{\delta}_{\mathbf{y}}$ & \multicolumn{2}{c}{ Stiffness } \\
\cline { 4 - 5 } & $(\mathbf{N})$ & $(\mathbf{m m})$ & $\mathbf{s}(\mathbf{N} / \mathbf{m m})$ & $\boldsymbol{\%} \mathbf{s}$ \\
\hline BTP & 17500 & 2.48 & 7056.45 & - \\
BPA1 & 28000 & 3.58 & 7821.23 & 10.84 \\
BPA2 & 25800 & 3.42 & 7543.86 & 6.91 \\
\hline
\end{tabular}

\subsection{Failure Mode}

The failure occurring in all specimens appeared in the same phases. Up to a load of $75 \%$ of the ultimate load which is the assumption of the first yield, the load-deflection curve shows a linear trend. Next, the slope of the load-deflection curve changes, indicating the reduced stiffness of the beam. Damage occurred from the outer fiber on a growing tension area towards the compression area between two loading points. The last failure phase was marked by the concrete crushing on the outermost compression fiber, indicating that the concrete had lost the ability to withstand the compression stress. The ultimate load to the beam without strengthening (BTP) was achieved at $17.5 \mathrm{kN}$ with a deflection of $18.50 \mathrm{~mm}$. The strengthened beam with end-anchor type 1 (BPA1) reached its ultimate load of $28 \mathrm{kN}$ with a deflection of $31.78 \mathrm{~mm}$, while the strengthened beam with end-anchor type 2 (BPA2) reached its ultimate load of $25.8 \mathrm{kN}$ with a deflection of 29.76 $\mathrm{mm}$. The failure mode of all specimens can be categorised as a flexural failure as seen in Figure 10.

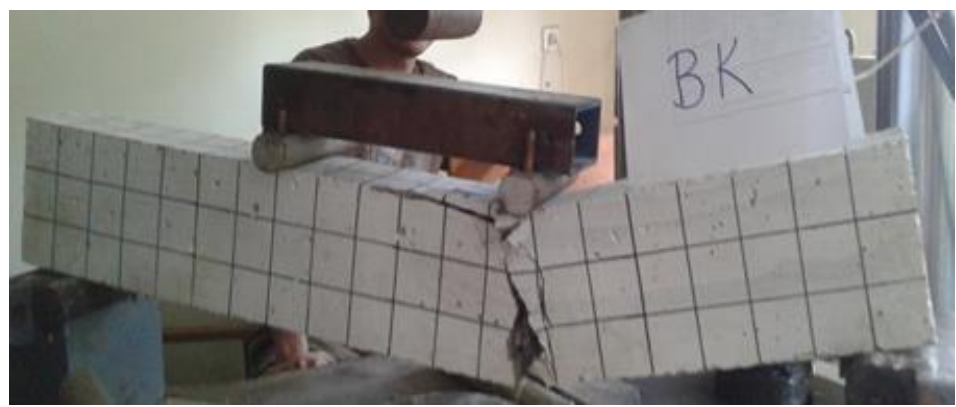

(a) 


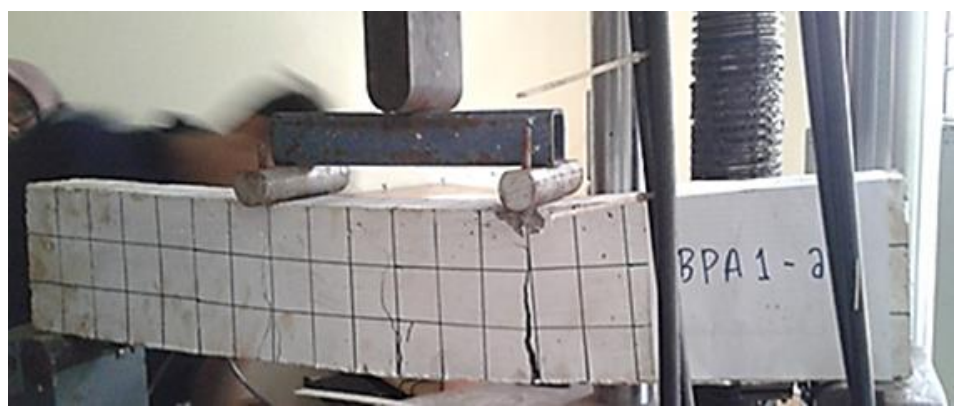

(b)

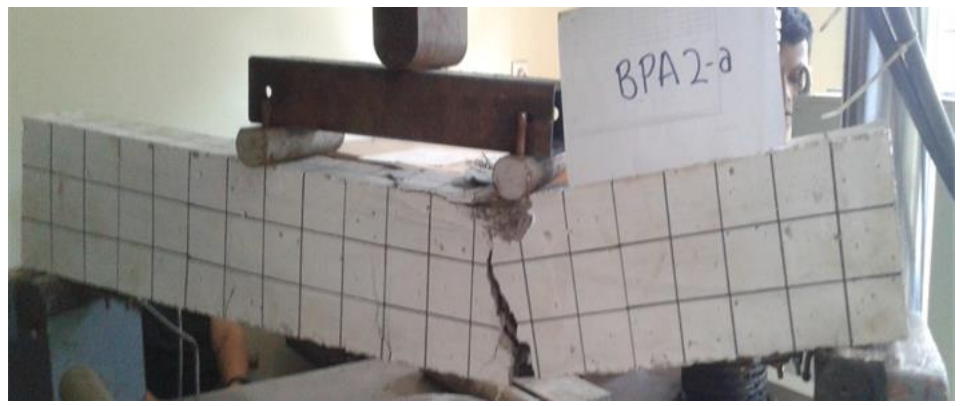

(c)

Figure 10 Failure mode of all specimens: (a) beam without strengthening (BTP); (b) strengthened beam with endanchor type 1 (BPA1); (C) strengthened beam with end-anchor type 2 (BPA2)

\subsection{CONCLUSION}

To conclude, the results of this study prove that using steel wire rope as the external strengthening of reinforced concrete beams has the advantage of better serviceability than unstrengthened beams. The reinforced concrete beams that are strengthened externally via steel wire ropes show a significant rise in load-carrying capacity with the increase of $60 \%$ and $47.44 \%$ respectively for BPA1 and BPA2. All specimens meet the minimum ductility requirements; in this respect, the strengthened beam has the advantage with an increase in ductility. This indicates that the steel wire ropes perform very well in improving the ability of the specimen to undergo inelastic deformation without substantially losing strength so as to prevent brittle failure. The increased stiffness in this study is associated proportionately with the increased strength. The strengthened beams had an increase in stiffness with $10.84 \%$ for BPAl and $6.91 \%$ for BPA2. The failure of all specimens appeared in the same phases and all specimens experienced flexural failure. Both end-anchor type 1 and end-anchor type 2 had a ratio close to 1 in all the parameters studied, which means that both types of end-anchor contribute equally well to the performance of steel wire rope as the external strengthening of reinforced concrete beams.

\section{Acknowledgements}

The authors would like to express their thankfulness to the Research and Public Services Institution (LPPM) of Jenderal Soedirman University for providing adequate fund through the Institutional Research Scheme to conduct this study. Besides that, the authors would like to express their deepest thanks to Dini Puspita Sari who was willing to offer support so that this study was able to achieve its goals. The authors would also like to thank the anonymous reviewers for their generosity in providing constructive comments which had helped to improve this paper.

\section{References}

[1] Pusposutarjo, S. 1993. Bencana Angin Topan di Indonesia: Kejadian dan Kesiapan Menghadapinya. Seminar PAU Teknik. Yogyakarta, Indonesia.

[2] Supriyadi, B. 1995. Mengantisipasi Pengaruh Beban Angin Topan Pada Struktur Bangunan Gedung. Seminar Nasional Bahaya Gempa dan Angin Topan Terhadap Struktur Bangunan Gedung. Yogyakarta, Indonesia.

[3] Hosen, M. A., Jumaat, M. Z., Darain, K. M. U, Obaydullah, M. and Islam, A. B. M. S. 2014. Flexural Strengthening of RC Beams with NSM Steel Bars. International Conference on Food, Agriculture and Biology (FAB-2014). Kuala Lumpur, Malaysia. 11-12 June 2014. 8-13.

[4] Haryanto, Y., Gan, B. S., Widyaningrum, A. and Maryoto, A. 2017. Near Surface Bamboo Reinforcement for Flexural Strengthening of Reinforced Concrete Beams. Jurnal Teknologi (Sciences and Engineering). 79(6): 233-240.

[5] Sukrawa, M., Sudarsana, I. K and Dana, I. W. 2011. Perkuatan Pelat Jembatan Dek Baja Dengan Overlay Beton Bertulang. Jurnal Teknik Sipil. 18(3): 207-216.

[6] Raoof, M. and Davies, T. J. 2003. Simple Determination of The Axial Stiffness for Large Diameter Independent Wire Rope Core or Fibre. The Journal of Strain Analysis for Engineering Design. 38(6): 577-586. 
[7] Avak, R. and Willie, F. 2005. Experimental Investigations and Modeling of Bond between Round Strand Ropes and Concrete. The $11^{\text {th }}$ International Conference on Fracture (ICF). Turin, Italy.

[8] Kim, S. Y., Yang, K. H., Byun, H. Y. and Ashour, A. F. 2007. Tests of Reinforced Concrete Beams Strengthened with Wire Rope Units. Engineering Structures. 29: 2711-2722.

[9] Yang, K. H., Byun, H. Y. and Ashour, A. F. 2009. Shear Strengthening of Continuous Reinforced Concrete TBeams Using Wire Rope Units. Engineering Structures. 31: 1154-1165.

[10] Yang, K. H., Kim, G. H. and Yang, H. S. 2011. Shear Behavior of Continuous Reinforced Concrete T-Beams Using Wire Rope as Internal Shear Reinforcement. Construction and Building Materials. 25: 911-918.

[11] Haryanto, Y. 2011. Efektifitas Wire Rope Sebagai Perkuatan Pada Daerah Momen Negatif Balok Beton Bertulang Tampang T. Dinamika Rekayasa. 7(2): 36-42.

[12] Atmajayanti, A. T., Satyarno, I. and Saputra, A. 2013. Pengaruh Penggunaan Wire Rope sebagai Perkuatan Lentur Terhadap Kekuatan dan Daktilitas Balok Beton Bertulang Tampang T. Konferensi Nasional Teknik Sipil 7 , Surakarta, Indonesia.

[13] Haryanto, Y., Wariyatno, N. G. and Sudibyo, G H. 2013. Pengaruh Gaya Prategang Awal Terhadap Efektifitas Wire Rope sebagai Perkuatan Daerah Momen Negatif Balok Beton Bertulang Tampang T. Seminar Nasional Teknik Sipil IX. Surabaya, Indonesia.

[14] Haryanto, Y., Gan, B. S. and Maryoto, A. 2017. Wire Rope Flexural Bonded Strengthening System on RC-Beams: A Finite Element Simulation. International Journal of Technology. 8(1): 134-144.

[15] Galuh, D. L. C. 2015. The Effectiveness of the Use of Wire Rope Flexural as the Negative Moment Reinforcement in T-Sectional Reinforced Concrete Beam. International Conference on Quality in Research, Lombok, Indonesia

[16] Sudarsana, I. K. and Widiarsa, I. B. R. 2009. Pengaruh Pemasangan Angker Ujung Terhadap Perilaku Runtuh Balok Beton Bertulang dengan Penambahan Lapis GFRP (Glass Fibre Reinforced Polymer). Jurnal IImiah Teknik Sipil. 13(2): 136-148.

[17] Jumaat, M. Z. and Alam, A. 2008. Behaviour of $U$ and L Shaped End Anchored Steel Plate Strengthened Reinforced Concrete Beams. European Journal of Scientific Research. 22(2): 184-196.
[18] Jumaat, M. Z. and Alam, A. 2009. Effects of Intermediate Anchors of End Anchored Carbon Fibre Reinforced Polymer Laminate Flexurally Strengthened Reinforced Concrete Beams. Journal of Applied Sciences. 9(1): 142148.

[19] Ahmed, E., Sobuz, H. R. and Sutan, N. M. 2011. Flexural Performance of CFRP Strengthened RC Beams with Different Degrees of Strengthening Schemes. International Journal of the Physical Sciences. 6(9): 2229-2238.

[20] Maryoto, A. 2015. Studi Komparasi Antara Angkur dari Baja dan Kayu untuk Prategang pada Beton Bertulangan Limbah Ban. Dinamika Rekayasa. 11 (2): 76-79.

[21] Apeh, J. A. and Okoli, O. G. 2016. Evaluation of Ductility Index of Concrete Beams Reinforced with Rebars Milled from Scrap Metals. Concrete Research Letters. 7(2): 56-68.

[22] Bsisu, K. A., Hunaiti, Y. and Younes, R. 2012. Flexural Ductility Behavior ff Strengthened Reinforced Concrete Beams Using Steel And CFRP Plates. Jordan Journal of Civil Engineering. 6(3): 304-312.

[23] Ashour, S. A. 2000. Effect of Compressive Strength and Tensile Reinforcement Ratio on Flexural Behavior of HighStrength Concrete Beams. Engineering Structures. 22(5): 413-423.

[24] Rashid, M. A. and Mansur, M. A. 2005. Reinforced HighStrength Concrete Beams in Flexure. ACl Structural Journal. 102(3): 462-417.

[25] Ho, J. C. M., Kwan, A. K. H. and Pam, H. J. 2004. Minimum Flexural Ductility Design of High-Strength Concrete Beams. Magazine of Concrete Research. 56(1): 13-22.

[26] Kwan, A. K. H., Shau, S. L. and Au, F. T. K. 2006. Improving Flexural Ductility of High-Strength Concrete Beams. Proceedings of the Institution of Civil Engineers: Structures and Buildings. $159(6)$ : 339-347.

[27] Priestley, M. J. N. 2003. Myths and Fallacies in Earthquake Engineering, Revisited. The $9^{\text {th }}$ Mallet Milne Lecture. Pavia, Italy.

[28] Pique, R. J. and Burgos, M. 2008. Effective Rigidity of Reinforced Concrete Elements in Seismic Analysis and Design. The $14^{\text {th }}$ World Conference on Earthquake Engineering. Beijing, China.

[29] LU, M. and Shi, Q. 2007. The Bend Stiffness of Crane Beam Strengthened with CFRP under Monotonic and Fatigue Load Condition. International Journal of Nonlinear Science. 4(1): 44-51. 